DOI

http://dx.doi.org/10.1590/2236-463320151013

A emergência de um ponto de vista cosmopolita: a experiência da História de Portugal na Universal History

\title{
The Emergence of a Cosmopolitan Point of View: The Experiencing of the Universal History's History of Portugal
}

$=$

Valdei Lopes de Araujo ${ }^{2}$

Universidade Federal de Ouro Preto,

Ouro Preto - MG, Brasil

email: valdeiaraujo@ichs.ufop.br

1

Doctoral student of History at the Federal

University of Ouro Preto. E-mail: andramos7@ gmail.com.

2

Professor at the Department of History of the Federal University of Ouro Preto. Researcher and Fellow. This article was developed for the collective research project, "Variedades do Discurso Histórico" (Varieties of Historical Discourse), financed by Fapemig's Pronem program for the support of emergent groups, coordinated by Núcleo de Estudos em História da Historiografia e Modernidade (Nucleus for the Study of History of Historiography and Modernity). We are grateful to all other members for the opportunity to debate it, as well as for their contributions, particularly to Thamara de Oliveira Rodrigues for reading the text. E-mail: valdeiaraujo@ichs.ufop.br.

\begin{abstract}
In this article we explore the British editorial project of the Universal History and its reception in the Lusophone world in the late eighteenth century. Focusing on the changes in the experience of history, we analyze how this project was designed to attend to the aspirations of an expanding readership and the rise of different temporal experiences existing in that world. We argued that these new expectations for a cosmopolitan view of the historical process couldn't emerge only from the boundaries of traditional narratives focused in rhetorical decorum and demands from the contemporary erudite scholarship in the academies. Lastly, we investigate how Antônio de Moraes Silva, a Luso-Brazilian man of letters, compiled and translated the History of Portugal from a French extended edition of the Universal History. Our main intention was to show how this edition highlights the impossibility of establishing a uniform and harmonious representation of the historical process and events in a context of dissolution of the traditional functions of historical discourse.
\end{abstract}

\section{Resumo}

Este artigo, analisa as transformações na experiência da história a partir do projeto editorial britânico da Universal History e da sua recepção no mundo lusófono no final do século XVIII. Investiga-se como este projeto foi empreendido visando atender aos anseios de um público leitor em expansão e como esse fenômeno afetou os modos de representar e experimentar a história. Uma nova visão cosmopolita do processo histórico precisou distender os limites tradicionais do decoro narrativo e das demandas por erudição vigentes nas academias ilustradas, emergindo paralelamente outras variedades de produção historiográfica. Na dimensão lusa, investigase como Antônio de Moraes Silva traduziu e compilou a História de Portugal a partir de uma edição francesa ampliada da Universal History. Procuramos demonstrar como as transformações dessa narrativa através das diversas edições sinalizam a crescente dificuldade de se estabelecer uma representação univoca e harmônica dos eventos e processos históricos.

\section{Keywords}

Modernity, Historiography, History of Ideas, Europe, Portugal

Palavras-chave

Modernidade, Historiografia, História das Ideias, Europa, Portugal 
3

Although our history concentrates on the modernization of the experience of history in dialogue with research in History and Historiography, the nature of the sources and assorted problems make the incursion into aspects of the history of the book, of printing and of reading inevitable. That's why we sought out some fundamental texts, without for that claiming to have exhausted the wealth of scholarly literature on this area of research. For an in-depth view of this field of studies in Brazil and its international interfaces, refer to DUTRA, Eliana de Freitas; MOLLIER, Jean-Yves. Política, Nação e Edição: o lugar dos impressos na construção da vida política. São Paulo: Annablume, 2006. RE: ABREU, Marcia; DEACTO, Marisa Midori. "La circulation transatlantique des imprimés» [electronic resource]: connexions. Campinas: UNICAMP/IEL/Secteur des Publications, 2014.

4

ABBATISTA, Guido. "The Business of Paternoster Row: towards a Publishing History of the 'Universal History' (1736-65)." Publishing History, London, n.17, p.5-50, 1985.

5

Currently, some researchers have taken up the issue. RE: ZANDE, Johan Van der. "August Ludwig Schlöser and the English Universal History." In: BERGER, Stefan; LAMBERT, Peter; SCHUMANN, Peter. Historikerdialoge: Geschichte, Mythos und Gedächtnis Im Deutsch-britischen Kulturellen Austausch 1750-2000. Göttingen: Vandenhoech Ruprecht, 2003. p.135- 156; LINK, Anne-Marie. Engraved Images, the Visualization of the Past, and Eighteenth-Century Universal History. Selected Proceedings from the Canadian Society for Eighteenth-Century Studies /Lumen : travaux choisis de la Société canadienne d'étude du dixhuitième siècle. Montreal, vol. 25, 2006, p.175195; BAÁR, Monica. "From general history to national history: the transformations of William Guthrie's and John Gray's: A general History of the World (1736-1765) in continental Europe." In: STOCKHORST, Stefanie. Cultural Transfer through Translation. Amsterdam-New York: Rodopi, 2010, p.63-82.
Introduction

Although today we see a relative consensus over the modernization of concepts which occurred between the eighteenth and nineteenth centuries-particularly in what concerns the modernizing process that became the basis of a Western culture founded on a historicist understanding of reality-much remains to be done about learning how that new experience of history came to be produced out of multiple ways of imparting meaning to events. The goal of this article is to contribute toward this body of knowledge by studying a case appearing to shed light on changes in the expectations of the European public concerning the experience of history. This article, therefore, offers an analysis of one of the most important historiographic experiments of the eighteenth century, with emphasis on the way it was intertwined with the modernization of the writing of history in the Lusophone world. We're talking about the publication of an extensive universal history in two parts, Ancient and Modern history, produced in the British world between 1736 and 1768, and which had broad repercussions in the Western scenario of the times. Our main focus on the Modern part will fall on the section dedicated to the history of Portugal.

For the Luso-Brazilian world, the consequences of that British enterprise unfolded at least until the early decades of the nineteenth century. The first version of a cosmopolitan history of Portugal was the object of translations, updates and changes in several editorial projects that sought to interpret a present temporality marked by multiple challenges and uncertainties. In this article, we will pay special attention to the history of the translation of the Portuguese part, made by Antônio de Moraes Silva, with emphasis on an effort to appropriate and change original meanings of the project in the different moments of its history. To that end, we divided the article in three parts. In the first, in dialogue with the specialized literature, we rescued the complex editorial history of the Universal History and its meanings for a history of the modernization of experience. ${ }^{3}$ In the second part, our analysis concentrates on the general trends of the History of Portugal as it appeared in the original Universal History, and the way it was changed and expanded in its French edition, the source of the first Portuguese translation. Finally, we will focus on the reception this "history of Portugal" had in the LusoBrazilian world, with emphasis on Moraes Silva's translation and expansion.

\section{A Universal History on an unprecedented scale}

Thanks to groundbreaking work of Italian historian Guido Abbatista, today we can have a glimpse of the Universal Historys relevance to the intellectual history of the eighteenth Century. ${ }^{4}$ Overshadowed by projects of greater critical acclaim, such as the Encyclopédie, the British initiative toward a universal history, though highly influential, with translations into several languages between the eighteenth and nineteenth centuries, ended up in relative oblivion. ${ }^{5}$

Designed first and foremost as a commercial venture aimed at the burgeoning book market of the time, the 'Ancient' and 'Modern' parts of the Universal History are separated by the great transformations of the eighteenth century, for the work announced in 1729 had its first part (Ancient History) published between 1736 and 1744, while the second (Modern History) appeared from 1759 to 1765 . As Abbatista pointed out, the men of letters these British publishers brought together far from represented the crème de la crème of the intelligentsia of the times, but rather stood for a new kind of learned professional ready to meet the demands of an enterprise not at all averse to risk taking: 
6

ABBATISTA, Guido. "The English Universal History: publishing, authorship and historiography in an European project (1736-1790)." Storia della Storiografia, Milão, n.39, p.102, 2001.

7

RE: LYNCH, Jack. "Orientalism as Performance Art: The Strange Case of George Psalamanazar." [sic] In: CUNY SEMINAR ON EIGHTEENTHCENTURY LITERATURE, 29 January 1999, Rutgers University. Available at: <http://andromeda. rutgers.edu/ jlynch/Papers/psalm.html>. Accessed on: 21 Feb. 2013.

8

For a deeper understanding of this question, RE: ARAUJO, Valdei Lopes de; PIMENTA, João Paulo. "História." Ler História. Lisbon, v.5, p.83-96, 2008. RE: COSTA, Wilma Peres. "Entre tempos e mundos: Chateaubriand e a outra América." Almanack Braziliense, São Paulo, n.11, p.5-25, May/2010. RE: RAMOS, André da Silva; RODRIGUES, Thamara de Oliveira. "Narrativas sobre a experiência da história contemporânea do Império Luso-Brasileiro: Hipólito da Costa e Francisco Solano Constâncio (1808-1810)." Revista do Instituto Histórico e Geográfico Brasileiro, Rio de Janeiro, n.463, April/ May/June, 2014

9

Based on the study of countless editorial projects for historical atlases across the 18th century, Manuel Schramm explores how the expansion of geographical knowledge about several parts of the globe enhanced the complexity of the providential and traditional forms of narrating history. RE: SCHRAMM, Manuel. The Beginnings of Historical Consciousness: Historical Atlases in the Eighteenth Century. Open Forum Ces Paper Series, n.21. Harvard: 2014-2015. p.1-50.
The authors who cooperated in successive moments-George Sale, John Swinton, George Shelvocke, George Psalmanazar, John Campbell, Tobias Smollett-mere mercenary writers, hardly heard of in the years that saw the birth of the work, with the partial exception of the valiant Arabist George Sale and of course, later on, of Tobias Smollett. None of them anyway ever was a Leibniz, a Vico or a Voltaire. ${ }^{6}$

Captain George Shelvocke had served as a corsair for Britain, and became famous upon publishing his travel narrative, $A$ Voyage Round the World by Way of the Great South Sea (1723). Yet the profile best representing the heterodox nature of the group was perhaps that of George Psalmanazar, a master impostor and fraudster, who turned his biography into an impenetrable mystery, to the point of people being fooled for quite a while into believing he was a Chinese immigrant who had converted to Christianity. Before joining the Universal History Project he already had gained a limited measure of acceptance in the literary and publishing milieu, having collaborated in the writing of pamphlets and reference works. ${ }^{7}$ Besides the "valiant Arabist" George Sale, the group also counted on successful and talented writers, such as the Scot John Campbell (1708-1775), a multifaceted author seen to rank among the most successful men of letters of the British publishing market, and who, for the Modern part of the Universal History, took charge of the History of Portugal, among other projects.

While admitting the plurality of a project spanning a significant stretch of the eighteenth Century, it is nonetheless possible to make some observations-as follow right below-toward a greater understanding of its role in the process of modernizing the experience of history. ${ }^{8}$ We will point out only some of those aspects, without delving very far into them. Firstly, evidencing some degree of awareness on the part of the publishers, the project produces an unprecedented revision of the idea of Universal History which, as a very ancient genre with a history marked by large gaps, sought to find its underpinnings for the modern era in the unity of the Christian world and its providential history. The British Universal History project issued from the assessment that these models were inadequate, and from the ensuing need to find new directions. ${ }^{9}$

1. The planet, and not Christianity, became the unit of reference for that history. The publishers were keen to narrate the events from all countries and nations known in the various continents. Even the Ancient section shows a conscious effort to move beyond Biblical geography. Therefore, an initial modernizing feature of the project consists in a geographic expansion of history, a trait that, for all practical purposes, coincided with that of a global history.

2. Although it started with the Ancient section, the second phase of the project advanced to the modern world in keeping with the same spirit of comprehensiveness driving the previous part. Here, too, they expanded the chronology, treating the Modern History section in just as dignified a manner as they had treated the Ancient one, and seeking to unify the different histories into a single chronological horizon.

3. As noted above, the project only became possible given the unprecedented existence of a rapidly expanding publishing market. The publishing capital allowed and required new contents for a new readership. This was a public who was not familiar with Latin as a culture language, and who was as eager to welcome the emerging form of the novel as it was in need of getting an education and some entertainment from the historic legacy of humanity. 
4. Once viewed as content to be made available to an expanding public, this historiographic legacy became the object of a great compiling and translating effort. Not being a learned public, this readership had neither access nor time to refer to the immense variety of texts containing the ancient and modern histories in question, especially those written in a foreign language such as Greek or Latin. How, for example, could an average British reader have access to the history of France chroniclers and historiographers had written in Provençal, French and Latin?

5. This new kind of history emerging from the new compilations set a different type of relationship between men of letters and readers in motion. Since, by definition, the public was not made up of specialized or erudite readers, it was incumbent on the narratives to perform a didactic tour de force in order to communicate their contents effectively. Given the huge size of a project that had certainly been thought out as a reference and consultation work, the editors sought to provide relief to their target audience through the massive deployment of long explanatory foot- and side notes designed to guide readers across the largely unprecedented experience of owning a complete history of "nearly" all of the world's nations.

6. As it was to be expected, given that these histories were produced from such a variety of sources for an also varied readership, their results were quite irregular and heterogeneous. The master lines of the dynastic histories remained as a kind of grid for the national histories, narrated mostly in keeping with the classical political and military definitions of the contents-all presented side by side, as pointed out above, with a marked presence of the culture of erudition evident both in the critical judiciousness, and in the presentation of detailed footnotes referring to the experts on the subject at hand. Clearly marked as well is the effort, on the one hand, toward understanding processes from the perspective of a narrative philosophy and, on the other hand, toward a greater inclusion of the anecdotal and the personal with the purpose of entertaining the readership.

7. The compilation model the project adopted corresponded to a weak version of authorship, at least if compared with that which would become the norm in the nineteenth century. Though this topic deserves further analysis, be it sufficient for our purposes here to note that this weak version of authorship spoke to the collective nature of that kind of publishing project, distributed as it was among large work teams and published in dozens of volumes over the course of years. This strategy made it possible to constantly "update" the histories by adding new "nations" and even by expanding the narrative, always toward the present. Just as in other intellectual activities, authors' remuneration depended more on the amount of work done than on the originality of their style or ideas.

In sum, compiling involved several different procedures: a) the "translation" of ancient original chronicles and texts-from the Greek, Latin, Arabic and several vernacular languages-which presupposed the existence of a community of men of letters who could read and decode such materials for the consumer/reader; $b$ ) the critical selection of the materials present in the primary (secondary) sources-a process that involved establishing the facts by comparison between the authorities, degrees of reasonableness, 
10

An Universal history, from the earliest account of time. Compiled from original authors; and illustrated with maps, cuts, notes, etc. With a general index to the whole. London: Printed for T. Osborne [etc.], 1736-1768. 65 volumes.

11

The Modern Part of an Universal History, from the Earliest Account of Time. Compiled from Original Writers. By the Authors of the Ancient Part. Vol. XXII. London: Printed for T. Osborne [etc.], 1760.

12

CANTWELL, Burton (Ed). Dictionary of national biography. Vol. VIII. London: Smith, Elder, and Co, 1886. p.373.

13

"To the 'Modern Universal History' he contributed the histories of the Portuguese, Dutch, French, Swedish, Danish and Ostend settlements in the East Indies, and histories of Spain, Portugal, Algarves, Navarre, and that of France from Clovis to the year 1656." NATIONAL BIOGRAPHY. Op. Cit., p.374.

14 Ibidem, p.375

15

In Campbell's biography, Dr. Kippis describes his sense of wonder about the text, and the mistake some more naïve readers may incur. Dr. Kippis. Biography. "The life of Dr. John Campbell, LL.D." The London Magazine Enlarged and Improved. Volume the Second, for January, February, March, April, May, June, 1784. p.343-349. consistency of the sources, etc; c) selection by means of cultural relevance. About this latter point, emphasis falls on a greater focus on the anecdotal and the singularity, as well as on a lay and ironical approach typical of the enlightenment, which not just rejected the miraculous and the fantastic, but also ridiculed it as a matter of principle. This was a history which also tended to be antipapal and anti-Catholic; d) the synthetic fusion of the materials critiqued primarily within the framework of national units, aiming at establishing a rigorous chronology of a politico-military and monarchical profile, but marked also by the clear presence of an effort to grasp the causes of accounted events, an attempt which, generally speaking, ended up referring to the "dispositions" of the populations and their rulers for an explanation.

\section{The History of Portugal in the Universal History ${ }^{10}$}

The part containing the History of Portugal in the Universal History was published in vol. 22, in 1760, with the work's narrative reaching 1714, not encompassing, therefore, events coeval with the referred volume. ${ }^{11}$ As mentioned above, the Portuguese part is attributed to the Scot man of letters John Campbell. What is thought to be his first original work, The Travels and Adventures of Edward Bevan, Esq., ex-London Merchant..., dates from 1739. According to the description found in the National Biography, this was a kind of fictional autobiography in the style of Defoe, which brought together information about the topography, history, natural products, political conditions and manners of supposedly visited countries. ${ }^{12}$ It was also at this time that Campbell began to collaborate with the Universal History, and that he was, for a while, mistakenly attributed the authorship of the Cosmogony, which as a matter of fact had been written by George Sale. For the Ancient part, Campbell wrote, "History of the Persians and the Constantinopolitan Empire," whereas for the Modern part he compiled the histories of the European presence in the East Indies, including that of the Portuguese. ${ }^{13} \mathrm{He}$ also wrote or compiled the histories of Portugal, Spain, and a significant part of the French History, beginning with Clovis I, and ending in 1656.

In 1741, at the same time he was writing about the "lives" of admirals and other important British navigators, as well as contributing to the Biographia Britannica with several profiles, Campbell published A Concise History of Spanish America. In 1750, he published The Political State of Europe, a collection of summaries of the histories of the European states, their international relations and home politics. Later republished in the periodical The Museum, apparently a widely read work at the time. Campbell's intense and diverse activities in genres which increasingly got the attention of a growing readership made him a wealthy man. ${ }^{14}$

With the publication in 1743 of his Hermippus Redivivus-a short book in which he purported to present a life-prolonging method allegedly learned in the works of ancient authors-Campbell showed he fit in very well with the eclectic team the Universal History project had set up. Although Hermippus Redivivus could readily be made for the satire it was intended to be once one learned that the "secret" of longevity lay in breathing in the same air the youth-especially, young women-did, the book's format apparently confounded some of its readers, who were unable to perceive the fakery concealed underneath the cloak of phony erudition that the author had spread over it. With a wink and a nod, the title already heralded, "...a Commentary Upon an Ancient Inscription, in which this Great Secret is Revealed; Supported by Numerous Authorities."15 
16

RE: KANTOR, Iris. Esquecidos e Renascidos: Historiografia Acadêmica Luso-Americana (1724-1759). São Paulo: Hucitec, 2004. RE: NICOLAZZI, Fernando F. "Entre 'letras \& armas', a história como disputa. Considerações sobre a historiografia luso-brasileira do século XVIII." Almanack Braziliense, v.11, p.40-51, 2010. RE: SILVA, Taise Tatiana Quadros da. "Maquinações da Razão Discreta: Operação historiográfica e experiência do tempo na Classe de Literatura Portuguesa da Academia Real das Ciências de Lisboa (1779-1814)." PhD diss. 2010. 312fls. Instituto de Filosofia e Ciências Sociais, Universidade Federal do Rio de Janeiro, Rio de Janeiro, 2010

17

MANN, M. L'Abbé. Dissertation sur L'Histoire Universelle (...). A Bruxelles : Chez Mathieu Lemaire, Imprimeur-Librarie, Rue de la Magdeleine, près I' Hôtel d'Angleterre, 1780. p.25-26.

18

Histoire Universelle, Depuis Le Commencement Du Monde Jusqu'a Présent (...). Composée en Anglois par une Société de Gens de Lettres; Nouvellement Traduite em François par une Société de Gens de Lettres; Enrichie de Figures et de Cartes. Histoire Modèrne. Tome TrenteTroisieme. Contenant I'Histoire du Royaume de Portugal. Paris: Chez Moutard [etc.], 1785.

19

The Monthly Review or Literary Journal. By Several Hands. Volume XXIV. London: Printed for R. Griffiths in the Strand, 1761. p.110-122 e p.120.

20

The Critical Review or Annals of Literature. By a Society of Gentlemen. Volume X. London: Printed for Hamilton, in Falcon Court, Fleet Street, 1762. p.161-178 and p.178.
The heterodox facet the Universal History compilers showed set them apart from the enlightened Ancien Régime academies. These institutes, which also adopted the methods of erudition, produced a kind of historiography closely tied to classical and monarchic forms of decorum, and concentrated on addressing an erudite audience made up of noblemen and/ or semi-specialized attendants. Their long and excruciatingly serious dissertations provided the textual underpinnings of general, ecclesiastical and/ or civic histories, many of which prioritized Latin as their target language of publication. The marked difference between the autonomous approaches that produced this variety of historical narratives explains why in the end of the eighteenth century the Portuguese men of letters found it necessary to have recourse to the Universal History in order to find a "modern" version of their national history, despite the existence of Luso-Brazilian academies. ${ }^{16}$

Early in 1741, the Ancient part of the Universal History began to appear in French, in an Amsterdam edition attributed to Guillaume Thomas François Raynal (1713-1796). As of 1779, a new version in French began to appear in Paris, edited by Nicolas-Léger Moutard (1742-18??), an edition which had its Modern part translated from the original, with "improvements." ${ }^{17}$ The volume with the history of Portugal appeared in French, in 1785 , and became the source of the first translation to Portuguese, made by Moraes Silva. The French version included new chapters with events of the history of Portugal until 1760. Also newly appended-in keeping with the end of century taste for overarching philosophical speculation essays-was the Introduction, "Description du Royaume de Portugal: Origine, splendeur et décadence de cette Monarchie." ${ }^{m 8}$

The reception of the first British edition of the history of Portugal can be mapped in part through reviews appearing in British periodicals. A commentator from the Monthly Review highlighted the memorial character of the work and quoted excerpts to show the greatness of the Portuguese accomplishments, and how these displayed "the most memorable particulars." In that sense, the rule of Dom Manuel I and the expansion of Portugal should be remembered as glorious and exemplary times in the history of Europe.

Of all the Kings of Portugal not one deserves to be more honorably mentioned than Emanuel, who became possessed of the crown in 1495: he was named the 'Fortunate' with great propriety; for his neighborhoods, as well as his subjects were partakers of his good fortune. To his sagacity and management must be attributed the discovery diffused throughout Europe. He was distinguished for being frugal without parsimony and generous without prodigality. ${ }^{19}$

On the other end of the spectrum, however, in 1762, a reviewer from Critical Review remarked on the Work's ambivalent relation with the chronicles seeking to memorialize the accomplishments of kings for all eternity, remarking that,

\footnotetext{
Upon the whole, though the reader will find nothing classical either in the style or composition of the Spanish and Portuguese histories, though the narrative is prolix and embarrassed, the characters dead and unenlivened, and the reflections trite, hackneyed and superficial; yet such is the variety and novelty of matter, that he cannot fail of being instructed and entertained..$^{20}$
}

For this reviewer, the histories of Portugal and Spain offered by the Universal History diverged from that in the works of the classical chroniclers-i.e. those from the twelfth to the seventeenth centuries; yet 
For an in-depth view in this context of historica distancing performances in British historiography and other literary genres refer to PHILIPS, Mark Salber. Society and Sentiment. New Jersey: Princeton University Press, 1997 some elements harking back to them were preserved, such as a distanced narrative evident in the unadorned characterization of the public virtues of the personages and the lack of significant philosophical reflection in the body of the Work. Thus the commentator from the Monthly Review stressed both the distance and proximity between the narratives of the Universal History writers and those of the chroniclers, implicitly affirming the positive effects of an increased historical distancing from the classical composition ideals. ${ }^{21}$ The benefits of this increased distancing took shape in the possibility for historiographic writing to overcome the bias of the chronicles concerned with contemporary events, incapable as they were to produce broad philosophical judgments about the historical process. The History of Portugal contained in the Universal History offered but "trite, hackneyed and superficial" reflections, although it could be viewed as a synthesis of the nation's development as a unit over time. Readers could grasp the causes of the progress and decadence of Portugal in this work, which offered its readership a diachronic synthesis of accomplishments encompassing around 500 years of history. Readers were given the opportunity to have a cosmopolitan experience of European and world history, even if the text lacked the philosophical point of view or judgment the century demanded.

Thus, in the reviewer's opinion, the Braganza "revolution" should be viewed as the most important event narrated in the History of Portugal, given that the authors of this work showed how, after the dynasties came together, the Spanish treated "Portugal as a conquered province." At this point, the reviewer thought it fundamental to highlight how the politico-administrative injustices of the Spanish crown made it impossible for the two kingdoms to be united. Still according to the reviewer, these acts of barbarity, arbitrariness and insolence had suppressed the power of Portuguese trade, tyrannically subdued the clergy and overwhelmed the population with heavy taxes. In fact, the reviewer from the Critical Review exposed the crisis of the conception of military virtue when he focused on the policies of the Spanish Crown in Portugal, given that the progress/commerce of Portugal was denied support once the kingdom was treated as a "conquered province." The Critical Review's commentator, therefore, read the History of Portugal in opposition to the works of the classical chroniclers, for the compilers of the Universal History pointed to the crisis of the conception of military virtue as they understood it to be in conflict with the moral and material progress of nations. The distancing from the chroniclers' conception of virtue influenced the method adopted in the work, in turn written as the result of a close reading and contrasting of several chronicles.

The twenty-second volume contains a minute and circumstantial history of the origin, rise, and progress of the Portuguese monarchy, deduced from a variety of Spanish and Portuguese historians. The most interesting event that occurs in the annals of this country is the famous revolution effected in the reign of Philip IV under the conduct of John duke of Braganza, afterwards raised to the throne of Portugal. Our authors have very accurately described every circumstance that gave birth to this grand revolt; the errors in Philip's administration, which laid the foundation of the Portuguese discontents; the breach of the fundamental articles, whereby the crowns of Spain and Portugal were united; the encroachments of the Spanish ministers; the total neglect of the Portuguese commerce, by which alone that kingdom was rendered considerable; the tyranny exercised over the clergy; the exorbitant taxes levied upon the people, and the wanton barbarities and insolences committed by Castilians, who, in all respects, treated Portugal as a conquered Province. These with a thousand other 
The Critical Review or Annals of Literature. Op. Cit., p.172.

23

Concerning the dissemination of commerce and the likely expansion of the personal conscience, Pocock distinguishes the immutable "classical republican virtue" from the mutable "modern virtue" because, for him, the former is inscribed in nature: "Montesquieu y otros teóricos sociales deberán concluir que la virtud espartana, romana o gótica, fundada en la posesión de la tierra por individuos austeramente independientes, era de una dureza inhumana y que solo com la expansión del comercio y las artes los hombres se socializaron y llegaron a adquirir la capacidad necessária para poder albegar sentimientos como la confianza, la amistad y el amor Cristiano." POCOCK, John G. A. El Momento Maquiavélico: el pensamiento florentino y la tradición republicana Atlântica. Madrid: Editorial Tecnos. p.532.

24

Concerning the role of this form of understanding history and the systematizing of it in the shape of macro narratives, Monica Baár, in writing about John Campbell, the compiler of the Universal Historys History of Portugal, states, "...the origins of the modern world, as described by the Scottish writer John Campbell, adopted the mainstream commercial narrative of the Scottish Enlightenment eulogizing commerce as a vehicle for progress and liberty." BAÁR, Monica. Op. Cit., p.64.

25

RODRIGUES, A. A. Gonçalves. A Tradução em Portugal. Vol.1. 1495-1834. Lisboa: Imprensa Nacional : Casa da Moeda, 1992. p.254, p.358 and p.369.

26

RE: MACEDO, José Agostinho de. "História do Reinado da Fidelissima Rainha D. Maria I nossa senhora." In: História de Portugal composta em inglês por uma sociedade de literatos. Transladada em vulgar com as adiç̃es da versão francesa e notas do tradutor português, Antônio de Moraes Silva, natural do Rio de Janeiro. Tomo IV. Lisboa: Oficina da Academia Real das Ciências, 1802. p.74-150 RE: COSTA, Hipólito José da. "História do Reinado de D. Maria I." In: História de Portugal composta em Inglês por uma sociedade de Literatos. Transladada em vulgar com as notas da edição francesa, e do traduto francês Antônio de Moraes Silva e continuada até os nossos tempos. Em Nova Edição: Book III. London: In the Offices of F. Wingrave, T. Boosey: Duau \& Co \& Lackington: Allen \& Co, 1809. p.214-248.

27

For an in-depth theoretical and methodological approach to this question, RE: PADILLA, Guillermo Zermeño. "História, Experiência e Modernidade na América Ibérica, 1750-1850." Almanack Braziliense, São Paulo, n.7, p.5-25, May/2008. RE: ARAUJ0, Valdei Lopes. "História dos Conceitos: problemas e desafios para um releitura da modernidade ibérica." Almanack Braziliense, São Paulo, n.7, p.47-55, May/2008. RE: PIMENTA, João Paulo Garrido. "História dos Conceitos e História Comparada: elementos para um debate." Almanack Braziliense, São Paulo, n.7, p.56-60, May/2008.

28

SILVA, Antônio de Moraes. "Prefácio do Tradutor." In: História de Portugal composta enormities, every day exercised by the haughty Spanish, determined the Portuguese to seek their remedy in a revolution and their courage. ${ }^{22}$

It was therefore possible for the British reader to identify the main elements, as defined by Pocock, of commercial humanism in Campbell's text. ${ }^{23}$ Even in the absence of the philosophical essay, the reader could assimilate the affirmation of the totality of civil life values based on a certain interpretation of European history as an advance from the times of "barbarism and religion" toward the age of commerce. ${ }^{24}$

Not satisfied with this description, the French translators and editors made more room for philosophical speculation in the Modern part. Moreover, the French edition displaced the long explanatory and erudite notes to the end of the book, given that in the British edition they had been indicated by letters placed at the bottom of the page. Though we cannot easily determine the significance of this shift, we can nonetheless speculate about its effects, for the French edition ends up displaying a lighter and less erudite appearance, despite the fact that the reference to the sources remain in the footnotes. That edition, and not the British version, would constitute the source for transposing that universe to the Portuguese language, as we shall see below.

\section{The transposition to Portuguese: Antonio de Moraes Silva and the hostile reception}

Upon translating the History of Portugal, Moraes Silva chose to include the French Introduction and give continuity to the narrative about the reign of Dom José I until 1777, that is, this was not a translation in the sense we understand one today, but rather an appropriation and continuation of a compilational history project. Other editions of this work appeared in Portugal in 1802, 1825 and $1828 .{ }^{25}$ From the 1802 volume onward, a closing chapter authored by José Agostinho de Macedo (1761-1831) discussing the rule of Dona Maria I was added. In England, Hipólito da Costa (1774-1823) published a version in 1809, also without altering the contents of the work Moraes Silva had translated and expanded, except for Macedo's chapter about Dona Maria I, which da Costa replaced with one of his own authorship because he considered it to be misconceived.

The successful fortunes of this project attest to the relevance of this text to Luso-Brazilian historical culture, given the several re-editions and controversies surrounding the reign of Dona Maria ${ }^{2 .}{ }^{26}$ The multiplicity of texts that went into its production speaks to the complexity of the historiographic relations among Portugal, England and France, and makes it impossible to reduce such connections to the unilateral category of 'influence.'27

The hybrid nature of the original British text (classical, erudite and, on a smaller scale, philosophical) seems to have determined how the Portuguese received a work that had been approved for publication by the censors and printed by the Royal Lisbon Academy of Sciences. In the Preface, Moraes Silva wrote that the history of Portugal could not rely just on the rosy lenses of the "ancient compendia," making it necessary to seek a broader understanding of the process leading to the formation of the kingdom. ${ }^{28}$ Despite the critique of the chroniclers, the positive aspects of their works should be spared, for military virtue was above being judged by the present with basis on mere distancing. The dignity of military virtue must be restituted, given that it was instrumental in preserving the unity 
em inglês por uma sociedade de literatos.

Transladada em vulgar com as adições da versão francesa e notas do tradutor português, Antônio de Moraes Silva, natural do Rio de Janeiro. Book I. Lisbon: Oficina da Academia Real das Ciências, 1788. p.1-4 and p.1.

29

História de Portugal composta em inglês por uma sociedade de literatos. Op. Cit. Book I, 1788, p.49.

30

Ibidem, Tome II, p.125

31

Ibidem, Tome I, p.72-73. of the Kingdom in the past. Thus, in the body of the main text translated to Portuguese it is stated that "a long line of warriors and prudent princes" enabled the unity of the "small Kingdom," spreading the glory of Portugal to "all corners of the world." ${ }^{29}$ Although this idealized perspective is still present in the work, other segments are found in it where the glories of the chroniclers are questioned. As the chroniclers sought to eternalize the examples of Royal accomplishments based on the direct interference of divine miracles, they became the object of criticism in the notes of the compilers, who thought that the reference to direct divine interference was reason to disqualify a chronicler's narrative. Moraes Silva chose to abide by this point of view, and translated the following note found in both the English and French versions: "The truth is that modern writers are less reprehensible than ancient ones, who often shaped their stories to suit their own ideas about the Justice of God." ${ }^{30}$ Thus Moraes Silva, in his translation and expansion of the History of Portugal, both adhered to the decorum of the chroniclers in that he included the narrative about the achievements and virtues of the kings of Portugal, and called into question the timeless exemplarity propounded by the chroniclers-a critical maneuver he accomplished by subjecting their narratives to the critique of erudition. As stated in the Portuguese translation, a narrative ought to be composed in "conformity to the best memories, deduced by collating the accounted deeds, which are our History's only reliable guides." ${ }^{31}$

Despite Moraes Silva's critique of the narratives of the Portuguese chroniclers in the Preface and the footnotes, the body of the work's translation did not deviate from giving predominance to classical and traditional themes, such as political and military feats. Just as the authors of the English and French versions had done in the preceding chapters, so did Moraes Silva, upon the end of the rule of Dom José I, abide by the dynastic chronology, writing an emotionally detached narrative of the monarchy's political and military accomplishments. As a whole, the work offers few philosophical judgments embedded to the Portuguese and foreign chroniclers' narratives of compiled facts.

Nonetheless, Moraes Silva incorporated the Introduction, "Description Du Royaume de Portugal: Origine, splendeur et décadence de cette Monarchie," found in the French version. In its first paragraph already, this introductory chapter reiterates a distancing from the chroniclers' historical horizons in relation to the present, revealing the work's character as an overarching philosophical synthesis. In fact, Moraes Silva's translation to Portuguese reads:

\footnotetext{
Having formerly integrated Spain, Portugal, like countless other regions, boasts an ancient origin that is lost in the darkness of times. The Portuguese authors would like their homeland to have been originally populated by Tubal and his family, whom they say founded a city he named after himself, and which still exists with the name of Setubal, a story they hold to be undeniable proof of what they say. Yet, the Spanish historians, no less proud of their origins than the Portuguese, dispute this evidence and proclaim the same Tubal as the founder of their monarchy. ${ }^{32}$
}

Ibidem, p.1-2.
The uncertainty surrounding the mythological origins based on a biblical tradition, as the chroniclers narrate them, becomes evident in the listing of the several peoples who lived in the geographical expanses of Portugal through the ages, such as the Turduli, the Belli, the Lusones, the Suebi, the Romans, the Goths and the Moors. ${ }^{33}$ Still with reference to the introductory chapter, the critique of the biblical/mythological perspective 
História de Portugal composta em inglês por uma sociedade de literatos. Tome I. Loc. Cit.

37

História de Portugal composta em inglês por uma sociedade de literatos. Tome I. Loc. Cit. is followed by an effort at a philosophical summary revealing the causes for the rise and fall of Portugal. If, on the one hand, "...among the modern nations, Portugal was at the forefront of enlightenment for numerous periods of time," on the other hand, the "kingdom has decayed since it became a Province of Spain by the force of arms." ${ }^{34}$ To understand the specificity of the rise and fall of Portugal, the Introduction offers short geographical sketches of the kingdom's provinces, including quantitative analyses of agricultural, commercial, industrial activities and the earnings of the public purse, and a scrutiny of the activities of the government, the clergy and the Inquisition, ending with a topic entitled, "Of the National Character."

Overall, the Introduction presents the image of a decadent kingdom which only after the Marquis of Pombal's administration does it show a relative measure of economic independence from foreign nations, given that the "benefits" he brings to the nation justify the "despotism of his government." ${ }^{35}$ The low agricultural production, the decrease in population, the waning of the arts, the shrinking of the public purse and the decline of the "military genius" are seen as the causes of the "the kingdom's inertia" in the eighteenth century, the negative effects of such unproductiveness extending as far as the "very fertile" lands of Brazil. ${ }^{36}$ This catastrophic state of affairs is explained as having been caused by Portugal's commercial dependence on England. ${ }^{37}$ In contrast to such poverty, the Pombal administration is described as the implementer of decisive measures leading to a more dynamic economy and a greater degree of freedom from England in trade matters. Here, the text highlights how Pombal's policies were in step with the ideals of the civilized nations, with their effects extending to the colonial administration, particularly that of Brazil.

\section{This minister [Pombal] was meticulous enough to extend to the colonies the same industrial ethos that he sought for the Kingdom. And, fully aware that slavery, at least in the modern perspective, desensitizes the soul and deprives men of their activity, he issued a decree whereby Brazilian Indians have their rights restored, allowing them to pronounce themselves as free as the Portuguese-an act of beneficence, rather than of justice, paying homage to humanity and shaming the other civilized nations which still have not imitated his example. ${ }^{38}$}

However, if in this specific instance Portugal is presented as a model for "the other civilized nations," Pombal's administration failed at making the kingdom overcome the barriers relative to "an unprecedented example of overwhelming national poverty." ${ }^{\text {"9 }}$ The "wise regulations" he had devised might have worked to overcome the difficulties the nation faced were it not for the "terrible catastrophe of 1755 " that befell Portugal with the earthquake. ${ }^{40}$ This mostly negative portrayal of Portugal ends with the topic, "Of the National Character," in which an anecdote is meant to reveal the Portuguese character:

\footnotetext{
Even though the Portuguese are held to be more industrious than their neighbors, more knowledgeable in matters of navigation and commerce, this did not prevent Lord Tirawleis from quipping about them, "What's to be expected of a nation, half of which hopes for the Messiah, and the other half for Dom Sebastião, a king who died 200 years ago?" But let that go as a frivolous memory. Yet, if it's true that the Portuguese had the advantage over the Spanish in navigation and commerce, it is also true that, having renounced their sense of worth, they have long remained behind them, even until today, in the building of an armed force and the establishing of military discipline. ${ }^{41}$
}

Even though Lord Tirawleis' remark is rejected as being shallow, one can understand that it was viewed as a lesson in ascertaining Portugal's 
42

Ibidem, p.36-37.

43

Ibidem, p.37-38.

44

Ibidem, p.1-2.

45

Ibidem, p.3.

História de Portugal composta em inglês por uma sociedade de literatos. Book I. Loc. Cit. decadence. For, if the Portuguese were considered to be more industrious than the Spaniards in navigation and commerce, the same superiority was nowhere to be seen in matters concerning military virtue, lost as they were in superstitious expectations over the return of the Messiah or of the King Dom Sebastião. That way, Lord Tirawleis' portrayal, caustic as it was, implied certain conclusions that an analysis of the kingdom's state of affairs could not ignore, given that Portugal's decline and its lagging behind the other nations were tied to the superstitious character of its people.

Moraes Silva did not pronounce himself about these critiques of Portugal's current state of affairs. Nonetheless, the moment the critiques in the Introduction came in confrontation with the institutions of the kingdom and were seen to question the absolute origin of royal power, they were quickly dismissed. About the Inquisition, the original French text stated that it was to be "feared even more in this kingdom than in Spain," and reminded the readers of this Institution's age-old responsibility for "censoring the books before they went to print." This form of control was key to keeping the population in ignorance insofar as "they only read uncritically about the lives of the saints, the histories of miracles operated with relics, and, perhaps, some fairy tales and the kinds of maxims which helped strengthen the clergy's control over the disposition of the people." ${ }^{\text {42 }}$ The argument goes on asserting that Pombal sought to confront this state of ignorance when he changed the book censorship regulations by extending the powers of secular magistrates and decreasing those of the Inquisition. Accordingly, auto-da-fé ceremonies and the sentencing of defendants could not be carried out absent the approval of the King..$^{43}$

Even though the Introduction of the translated French original did present this caveat, Moraes Silva made a point of noting in the Preface how the Inquisition Tribunal, such as it functioned in Moraes Silva's times, did not pose an obstacle to the kingdom's development. According to Moraes Silva, defending the Tribunal in this way was necessary because he had chosen to maintain the "integrity of the original," and thus included the "translation of some passages where the authors of this work had disrespected the Royal Tribunal." Thus Moraes Silva explains that, during the reigns of Dom José I and Dona Maria I, the sentences meted by this tribunal were "gently and humanely" applied, evidencing "the correct procedures of this righteous Tribunal, especially in response to the new regulations." ${ }^{44}$

Moraes Silva sought to show how, instead of opposing the progress of Portugal, the Inquisition acted to rehabilitate those accused of crimes of lèse majesté, who, in other nations were routinely sentenced to death. The translator also notes the historical importance of the Inquisition for the kingdom as he demonstrates its key role in maintaining the unity of the Monarchy during the "calamitous times of the purported Reformation," in which countless wars of religion broke out across Europe. In that way, introducing the Inquisition in the realm "had beneficial results which more than made up for the deleterious effects of the few imperfections that must inevitably seep into human affairs." 45 Therefore, according to Moraes Silva, given that human nature is fallible by definition, it was impossible not to criticize the Inquisition. However, once the virtuous Institution became aware of its errors, it sought to correct them, leaving no doubts as to "the extent to which our August and Very Pious Queen, with all her goodness and clemency, has influenced the kindness and humaneness with which inquisitions proceed in this Kingdom." ${ }^{\text {"46 }}$ 
Ibidem, p.36-37. Our emphasis in boldface.

48

For a study of reading practices in the context of the enlightenment reformation, which emerged in association with a new understanding of history that could distinguish present from past, and that argued against the traditional forms of representation, refer to: VILLALTA, Luis Carlos. "Libertine readings in Portugal and Brazil (c. 1746-1807)." In: ABREU, Marcia; DEACTO, Marisa Midori, La circulation transatlantique des imprimés. 0p. Cit., p.103-111.

49

For an in-depth study of the relationship between historiographic practices and the enlightenment reformation policies of the Royal Lisbon Academy of Sciences, refer to: SILVA, Ana Rosa Cloclet da. Inventando a Nação: Intelectuais e Estadistas Luso-Brasileiros na Crise do Antigo Regime Português (1750-1822). São Paulo: Hucitec, 2006. RE: SILVA, Taise Tatiana Quadros da. Op. Cit.

50

ABREU, Márcia. "O Controle à Publicação de Livros nos Séculos XVIII e XIX: uma outra visão da censura." Revista de História e Estudos Culturais, Uberlândia, v.4, year IV, n.4, p.1-12, Oct./Nov./Dec. 2007. For a deeper understanding of this question refer to, VILLALTA, Luis Carlos. "Censura Literária e Circulação de Impressos entre Portugal e Brasil (1769-1821)." In: DUTRA, Eliana de Freitas; MOLLIER, Jean-Yves. Política, Nação e Edição. São Paulo: Annablume, 2006. p.111-134.
Thus Moraes Silva defends the Inquisition by arguing that it had been involved in past excesses and barbarisms analogous to those committed in other European nations. Nevertheless, its current procedures demonstrated the ability of the enlightened Portuguese monarchs to carry out reforms and overcome the obstacles placed in the way of the kingdom's progress. In this sense, the author reiterates in an endnote that which had been stated in the Preface:

As part of the effort to undercut the very deathly consequences of the errors of Luther, Calvin and others, the Inquisition found it expeditious to become involved in all seriousness in the censorship of books. And we are all aware that the ensuing contentions led to many truths being worked out and many others revealed, yet they were like chaff and wheat, that is, they came in the company of many mistakes or inserted in evil books. It may well have acted with excessive stringency when it proscribed the comedies of Sá de Miranda, Antonio Ferreira and others, plays currently being staged, and which at the time were presented before King Dom João III and Cardinal King Dom Henrique, General Inquisitor. Perhaps it may have been overly indulgent with books of pious credulities or which teach things of the kind. But then, those were faults of the age. At a later date, when pure lights began to shine on this Kingdom, and the Inquisition began to include those who had opened their eyes to them, the censorship function was transferred to The Crown Tribunal of the Board of Censors. So, reader, just consider the prudence with which the changes will be made to the better in the opinion of the population, a population from all classes, who believe because they believe. All innovations in perspective have led in the same path, and there are none today who are not astounded by the imperfections of twenty years ago. ${ }^{47}$

Therefore, the excesses of the Inquisition ought to be judged by taking into account the specific historical context in which they were perpetrated. Nonetheless, Moraes Silva's review suggests grounds for agreeing with the critiques of the French philosophic synthesis since, given the excessive credulity of the population, this institution had been able to perpetuate its negative historical presence even in the eighteenth century and against the progress achieved over the past twenty years, the time when the "pure lights began to shine on this Kingdom." Moraes Silva's statements walk the fine line between contextualizing the past and judging it based on its effects on the present. ${ }^{48}$ By suggesting a Portugal both pregnant with progress and immersed in ignorance, Moraes Silva clearly pointed to the uncertainties surrounding the meaning of a historical distance between the Kingdom's past and present.

Despite the ambivalence of his defense of the historic role of the Inquisition, Moraes Silva's observations may be viewed as being engaged in dissipating the doubts over the monarchy's power to advance progress in the Portugal of his time. Thus, the translator's Preface and notes met the historiographic requirements of the Royal Lisbon Academy of Sciences, which allowed the work to be printed, for it aimed both at updating Portugal on the literary advances in other nations-particularly in Great Britain and France-and at restating the importance of the kingdom's institutions from the point of view of an enlightened reformation. ${ }^{49}$

In recent studies, Marta Abreu investigated cases in which Portuguese censorship boards of the late eighteenth and early nineteenth centuries allowed the publication of foreign works disseminating political, religious and moral perspectives that subverted Royal policies, with commentaries in attached prefaces and notes from the censors in charge of correcting opinions. As the arbiters of culture, censors combated the plurality of corrosive ideas with references to Reasons of State. ${ }^{50}$ The 


\section{1}

Some passages in Moraes Silva's biography lead us to ask whether his intention when he chose to include the critiques the French source made of the Inquisition and then defend that institution in a rather ambivalent way, wasn't to stress the legitimacy crisis the Inquisition was undergoing at the time. Moraes Silva presented himself to the Inquisition of Coimbra on May 28 1779, after having been accused by Francisco Cândido Chaves of, together with some of his fellow students, disrespecting the Catholic rites and dogmas when discussing religious themes, frequently quoting Voltaire, Rousseau and Helvetius. Before the Holy Office, he said that he and his mates had staged a phony Masonic ritual to lure Chaves into the order. Upset with the practical joke, Chaves had denounced his fellow students. Moraes Silva escaped before the Holy Office's sentence was meted out, ordering the incarceration of all those involved. Moraes Silva returned four years later to Portugal, bearing a laissez-passer issued by the Holy Office, and on January 21st, 1785, he appeared before the Inquisition Board, now in Lisbon. He confessed his regrets for the errors of his ways as a student in Coimbra, and was sentenced to pay spiritual penance and bear with the prosecution costs. In 1806, the Holy Office received new accusations claiming Moraes Silva to be lacking in religion. $\mathrm{He}_{\text {, }}$ at the time, was living in the district of Moribeca, in the province of Pernambuco. The Inquisition, however, shelved the accusations. RE: BAIÃO, Antônio. Episódios dramáticos da Inquisição Portuguesa. Rio de Janeiro: Tipografia do Anuário do Brasil, 1924. v.2, p.101-122. RE: MENEGAZ, Ronaldo. "Antônio de Morais Silva (1757-1824)." Revista Convergência Lusíada, Rio de Janeiro, Real Gabinete de Leitura, n.24, p.337341,2 nd semester of 2007. RE: BARATA, Alexandre Mansur. Libertinos, Afrancesados e Pedreiros-Livres. Maçonaria, Sociabilidade Ilustrada e Independência do Brasil (1790-1822). Juiz de Fora: UFJF, 2006. p.31-80.

52

PINTO DE SOUZA, José Carlos de. Biblioteca Histórica de Portugal, e seus Domínios Ultramarinos. Lisbon: Tipografia Calcograffica, Tipoplástica, e Literária do Arco do Cego, 1801. p.394.

53

Ibidem, p.392.

54

Ibidem, p.393.

55

Ibidem, p.346-347.

56

DUCKET, M. W. (org.). "Dumouriez" In: Dictionnaire de la Conversation et de la Lecture. Par une Société de Savants et de Gens de Lèttres. Tome Huitième. Seconde Édition, Entièrement Refondue. Paris: Michel Lévy, 1854. p.161-162.

57

PINTO DE SOUZA, José Carlos de. Op. Cit., p.346-358. continual reediting of Moraes Silva's translation of the History of Portugal throughout the early decades of the nineteenth century shows that his coevals interpreted the observations he made in the Preface and notes as defending the Inquisition and the Kingdom's institutions..$^{51}$

In Biblioteca Histórica de Portugal e seus Domínios Ultramarinos (1801), José Carlos Pinto de Souza states that the translation of the second French edition of Histoire Universelle, contains a great deal of disinformation about the kingdom of Portugal, inserted with the objective of disparaging it, but "against which our learned translator cautions the readers by means of his knowledgeable annotations." ${ }^{52}$ De Souza further notes that the French edition includes the chapter, "Description du Royaume de Portugal," "whose authorship appears to be of a character similar to that of the above-heralded État present du Royaume de Portugal, if not the very same, as it can be perceived in the extracts it contains. ${ }^{\text {"53 }}$ De Souza devoted a few paragraphs to arguing against the observations disseminated in the Introduction of the work translated by Moraes Silva. One of the passages he discussed was Lord Tirawleis' anecdote. ${ }^{54}$ According to De Souza, the Introduction, overall, deserved to be rejected for the same reasons outlined for État présent du Royaume de Portugal, a work discussed in the preceding pages.

De Souza starts his commentary on this work-published in 1766 and 1775-by identifying its author.

It is of public notoriety that its author is the famous and well known Mr. Dumouriez, who in 1792, at the time of the hateful revolution in France, joined the rebel party. Later, as a rebel general fighting against Holland in the Low Countries, an order for his arrest was issued, upon which occasion he escaped to Germany, but not before having stolen from the Military Savings Bank. Previously to the above mentioned revolution he also stayed at the Portuguese court, which as far as it is known, refused to give him what he wanted and, because of that, he left it a disgruntled man. Disoriented or just drunk with himself, he set out in shameless temerity to write the above-mentioned work with the objective of demeaning Portugal, but in the process exposing his crass ignorance of the History of this Kingdom, as the following extracts demonstratively prove. ${ }^{55}$

Charles-François du Périer Dumouriez (1739-1823) was general of the revolutionary army during the French Revolution. He deserted and turned into a monarchist at the service of the British government in an advisory function during the reign of Napoleon. ${ }^{56}$ De Souza describes him as a "reckless impostor" and refutes many of his observations about Portugal appearing in several works other than État présent du Royaume de Portugal. In this entry, De Souza unequivocally states, that the Introduction to Histoire Universelle had been written by Dumouriez, to whom he attributes the exclusive responsibility for the mistakes of erudition as well as the prejudices pervading the French edition that Moraes Silva translated. ${ }^{57}$ In fact, as we pointed out above, De Souza's categorical affirmation about the authorship of the Introduction was questioned in a later entry about the Histoire Universelle. Nonetheless what matters most here is to stress that De Souza defamed the character of this translated work and emphasized the "knowledgeable notes" by the "learned translator."

In spite of De Sousa's failure to prove that Dumouriez was the author of the introduction to the Histoire Universelle, the structural similarities between the French work État présent du Royaume de Portugal and the "Description du Royaume de Portugal" are undeniable. For one, both texts start out by drawing a geographical portrait of Portugal; and, then, both 
RE: DUMOURIEZ, Charles-François du Périer. État Présent du Royaume de Portugal. Lausanne: François Grasset \& Comp., 1775 set out to cover topics such as the colonial economy, the Military situation of the Kingdom, the enforcement of laws justice, the operations of the Inquisition, ultimately aiming at defining the "caractère national" of the lands under observation by describing the manners and customs of the local populations. It should be noted that, in the Portuguese translation of "Description du Royaume de Portugal," these topics are developed in fortytwo pages, whereas in Dumouriez's work they take up three hundred and four. ${ }^{58}$ The structural similarity between the texts, together with De Souza's critique, suggests that the Introduction translated by Moraes Silva found inspiration in Dumouriez's work.

Nonetheless, in a context where the compilational method conflicted with the full consolidation of an authorial subjectivity, it should be noted that it was impossible for Moraes Silva's version of História de Portugal to be peacefully received by the intellectual milieu of Portugal. The ensuing discussions between Agostinho de Macedo and Hipólito da Costa, as well as the critiques of De Souza, showed how, in this context, the Portuguese historical experience was entangled in conflicts that could hardly be resolved by a man of letters engaged in writing the history of the Kingdom. Confronted with the need to catch up with the literary, social and economic progress of other nations, and on facing the assertion of the singularity of the Portuguese institutions, the reformation policies in force in the Luso-Brazilian world allowed the circulation of enlightened historiographic perspectives of a radical nature-points of view which, despite having been submitted to "correction" by the Reasons of State in the notes and prefaces, still challenged the State's purported eternity and its statute as moral arbiter by exposing their readerships to a diversity of narratives dealing with the same processes and events.

Translated by Luiz A. da Silveira 